\title{
INFLUENCE OF MULTINATIONAL ENTERPRISES ON LOCAL INDUSTRY UPGRADING IN GEORGIA
}

\section{INFLUENCIA DE LAS EMPRESAS MULTINACIONALES EN LA ACTUALIZACIÓN DE LA INDUSTRIA LOCAL EN GEORGIA}

\author{
Shorena Kurdadze \\ Caucasus International University, Tbilisi (Georgia) \\ Shorena.kurdadze@ciu.edu.ge \\ https://orcid.org/0000-0001-7806-1944
}

\begin{abstract}
The purpose of this research is to identify the impact of the Foreign Direct Investments motivations in Georgia and to study their influence on the country's economy by considering sector and country characteristics. To assess the impact of foreign direct investment motivation on local economies, the author interviewed companies operating in Georgia in 20092016. Then, because the measurement scales used in the survey were mainly binary and ordinary, the author used ProbiT Regression and Ordered ProbiT Regression models. Results obtained from surveys and from analyses using regression equations show that natural resourceseeking companies use local goods and services in their production processes; this is expressed in their linkages with local suppliers and distributors. Conclusions are that foreign direct investments in Georgia have no significant influence on the development of local organizations and innovations. Although the Georgian market is small and the population is quite poor, market-seeking foreign direct investment is predominant. Multinational Enterprises that are directly engaged in foreign investments in Georgia (except for natural resourcesseeking foreign direct investments), are rarely integrated with local markets.
\end{abstract}

Keywords: Foreign Direct Investment (FDI); OLI paradigm; Transition Economy; Regression model; FDI motivations

\section{Resumen}

El propósito de la investigación es identificar el impacto de las inversiones extranjeras directas (IED) que se producen en Georgia y estudiar su influencia económica tomando en consideración las características del sector y del país. Para evaluar el impacto de la motivación de la inversión extranjera directa en la economía local, se entrevistó a las empresas que operaron en Georgia entre 2009-2016. Las escalas de medición utilizadas en la encuesta fueron principalmente binarias y ordinarias, por lo que se utilizó el modelo de regresión ProbiT y el modelo de regresión ProbiT ordenada. Los resultados de las ecuaciones de regresión muestran que las empresas de recursos naturales y utilizan los recursos locales en su producción, muestran vínculos con proveedores y distribuidores locales. Las conclusiones son que la influencia de las inversiones extranjeras directas en Georgia no es significativa en el desarrollo de organizaciones e innovaciones locales. Aunque el mercado georgiano es pequeño y la población está necesitada, la IED en busca de mercado es predominante. Las Empresas Multinacionales (EM) que participan directamente en inversiones extranjeras en Georgia (a excepción de las de recursos naturales que buscan IED) rara vez se integran con el mercado local.

Palabras clave: Inversión extranjera directa (IED); Paradigma OLI; Economía de transición; Modelo de regresión; Motivaciones de IED

Como citar este artículo/ citation: Kurdadze, Shorena (2020). Influence of Multinational Enterprises on Local Industry Upgrading in Georgia. ANDULI, 19, 2020, pp. 81-98, https:/10.12795/anduli.2020.i19.04 


\section{Introduction}

The growing significance of FDI from emerging economies has led a number of authors to research the motivations of this phenomenon (Kottaridia, Giakoulas , \& Manolopoulosb, 2019). FDI exerts a significant and positive impact on economic growth, along the complementary positive impact of domestic investments on economic growth (Silajdzic \& Mehic, 2015).

The FDI is associated with the inflow of unique assets in the country, such as new technologies, know-how, innovations, management skills, etc. However, at the same time many empirical researches indicate that the impact of foreign direct investments may not be positive for the economy of the recipient country (Nistor, 2015), (Sikharulidze, 2012)especially for developing countries, which have different possibilities to absorb FDI benefits. Based on the research the author conducted in 2015, FDI has crowding out long-term effect on investment in Georgia (Sikharulidze, Kurdadze, Tordinava, 2015). The data used for FDI and domestic investment were inward FDI flows to the country and gross capital formation, respectively (post-1990 period).Fore exploring the impact of FDI in more details in this paper we have used different methodology, based on micro level data which is described below.

Transition to market economy, as Georgia was member of the Soviet Union from 1921 to 1991, was quite difficult for Georgia- tense political environment, criminal situation, lost territories, civil wars, loss of economic ties, hyperinflation and many other factors made the country non-attractive for the FDI. The reforms carried out during the last 25 years have significantly accelerated the process of integration of the country into the global economy, which facilitated Georgia to become the prospective country for investment. This process was further deepened by signing of the Association Agreement between the EU and Georgia in 2014, which envisages the Deep and Comprehensive Free Trade Area Agreement. Although the FDI has been characterized by a growing trend in Georgia over the years (if not considering the sharp decline in 2007-2008), they could not address the socio-economic problems in the country, such as significant improvement of employment indicators and export potential, distribution of new knowledge and technologies, etc.

FDl's calculation in Georgia has been carried out since 1997. After Georgia's independence, it was distinguished by its location and cheap labour. At the initial stage, investments in Georgia were entirely on regional gas pipelines. At the next stage, foreign companies were able to utilize the ownership advantages, which caused attracting more investments in different fields. The maximum amount of direct foreign investments in Georgia was recorded in 2007. From 2008 to 2013 FDI is falling continues to grow from 2014 (Kurdadze, 2018).

Based on the empirical data, when local firms are purchased by the MNEs, additional capital much more efficiently improves the country's macroeconomic indicators. According to many authors, foreign affiliate companies are more export oriented and more actively using qualified staff (Hu \& Jefferson, 2002), (Khaturia, 2002).

Researches by Georgian scientists and economists have been conducted on the example of Georgia in order to evaluate the impact of the foreign direct investment on the economic development of the country. However, it is noteworthy that the foreign direct investments in the sectorial level are less studied. This factor stipulated our interests in this issue and consequently we decided to conduct research on the micro level - to study the motivations of foreign direct investments in Georgia and evaluate their impact on the local industry upgrading. The research is based on the 
eclectic paradigm by John Dunning (OLI: O - Ownership advantages; L - Location advantages; I - Internalization advantages) and the investment model by Joanna Scott Kennel. The thesis makes analysis of the FDI motivations (natural resources seeking, market-seeking, efficiency-seeking and strategic assets seeking), and the role of each of them in the local branches renewal process - in correlation with the eclectic paradigm, which is used for assessment of the linkages between the foreign direct investment and economic development.

According to the eclectic paradigm, the country's investment development depends on advantages of the ownership advantages of MNEs, the advantages of location of the country and internalization (Dunning, 2000). The paradigm indicates that the investment development of the country depends on the advantages of ownership of local organizations $(\mathrm{O})$ and the spread of these advantages by foreign companies. Consequently, foreign direct investments have an indirect effect on the improvement of the ownership advantages of local firms through which international trade is developing in the country. Nevertheless, according to Scott Kennel, the use of this potential depends on types of incoming foreign direct investments in the country, location and government policy (Scott-Kennel, 2010). On the other hand, Scott Kennel's model is based on John Dunning's OLI paradigm.

One of the most important parts of the survey - the questionnaire - is formulated according to the model by Scott Kennel; based on this questionnaire 97 organizations operating in Georgia have been interrogated (data in general - 2500). According to this model, the process of development of the local sector consists of four stages: the first stage is to enter the market, the second stage is the establishment of ties with local organizations, the third stage is the distribution of ownership advantages and the fourth stage is to increase ownership advantages, showing the interconnection of the foreign direct investments and local organizations from enclave through full integration. Based on the data of MNEs in Georgia, the thesis explains specifically this process; on the basis of the mentioned statement it is calculated the impact of foreign direct investments on the modernization of local industries according to the number and frequency of linkages.

The goal of the research is to identify the impact of the FDI motivations in Georgia and study their influence on the country's economy by considering the sector and country characteristics.

\section{Research tasks:}

- Calculating degree of MNEs' integration with the local economy according to FDI motivations;

- Determining the influence of MNEs on export growth;

- Determining the influence of MNEs on the spread of new knowledge;

- Identifying the level of competences of local companies and the potential for establishing links with MNEs;

- Revealing the characteristics of the country that facilitates the growth of FDI benefits.

\section{Novelty of Research:}

- On the basis of the OLI paradigm the model of impact of the foreign direct investments on the country's economy has been developed, which determines the degree of integration of MNEs into the local sector, starting from enclave through the full integration. 
- Main motivations of the FDI implemented in Georgia are revealed. Their impact on the modernization of local industries by the number and frequency of links has been also calculated.

\section{Materials and Methods}

Based on the objectives and tasks of the research, the following information was required: export and import operations of MNEs, cooperation with local organizations, local population employment index, their link with local research centres / universities, innovations indicator, etc. We have addressed the Ministry of Economy of Georgia and the National Statistics Office of Georgia (hereinafter the Geostat) to obtain this information. Since such information did not exist in state organizations, we decided to conduct quantitative research - collecting data through the questionnaire.

To assess the impact of foreign direct investment motivation on the local economy, the companies, operating in Georgia in 2009-2016, were interviewed. The list of firms and contact information is provided by the Geostat.

In addition, we have also the list of top 50 companies delivered by the Geostat in 2015 according to the volume of investments made in 2009-2015. Online, telephone and face to face communication were applied during the data collection. General number of companies is up to 2500.97 organizations have been interviewed in total, $95 \%$ confidence interval is $10 \%$. The questionnaire consists of 33 questions which are distributed in 4 sections - general information about the organization and its activities; motivations of foreign direct investments and factors affecting it; ties between MNEs and local organizations; introduction of innovations. Most of the questions were multiple choice type. Respondents received the link of a questionnaire by the email in the Georgian and English languages, along with the interpretation of the questions and the author's contact information. A telephone interview was held with up to 60 organizations that helped to fill the questionnaire. The emails failed to reach about 650-700 addressee. In addition, messages were also sent to respondents where we asked them to participate in the survey. For this purpose we called them on their phone numbers. Some of them refused to fill out an electronic questionnaire, although they agreed to a telephone interview. Finally, we can say that data is a cross, since it was collected in about the same period of time (December 2016 - March 2017).

In the course of collection of data we used the categorical (measuring nominal and ordinary scales) and quantitative data (interval and relative scales). Namely, the nominal scale indicates the sartorial distribution of companies. In the ordinary scale, a large number of questions are given where the respondents assess the degree of significance of different issues within the range of scores from 0 to 4 points, such as the impact of the government regulations on their activities, the formation of links with local firms, the quality of the impact of various problems on their sector and others. The interval scale includes data such as market share in Georgia, export and import (selective answers are in given in percentages, with an average $20 \%$ interval).

After the collection of data, we made frequency distribution through columns and circuit diagrams, as well as calculating the mean values of some issues was done. The study provides an analysis of the impact of foreign direct investment motivations on the local industry upgrading of the recipient country through the Probit Regression model. Computer software stata for data processing was used. 


\section{Probit model for binary and ordinary variables}

As already mentioned, the measurement scales used in the survey are mainly binary and ordinary, so we used ProbiT Regression and Ordered ProbiT Regression model. Taking into consideration the possibilities of modern computers, the most difficult aspect of probit models is related to submission and interpretation of the outcomes. With all software packages of the probit model it is possible to calculate the values of the coefficients, their standard errors and the functionality, after which all of these values should be reflected in the account report. That is how we interpret the results of our research and reveal the results. While some of the variables derived from the research are not statistically significant, analysis of the coefficients gives us an opportunity to find out in which direction they can impact the dependent variable.

\section{Results}

The results of the study are distributed into three sections: frequency analysis with figures, tables and schemes; analysis of average indicators and Frequency of linkages with local organizations.

\section{Frequency analysis}

Most of the surveyed companies are represented from the fields of trade and construction, followed by financial and healthcare sector. Overall, 97 companies have completed the questionnaire.

Table 1. Distribution of surveyed companies according to sectors

\begin{tabular}{|l|c|c|}
\hline & Sector & Number of surveyed companies \\
\hline $\mathbf{1}$ & Trade & 22 \\
\hline $\mathbf{2}$ & Construction & 16 \\
\hline $\mathbf{3}$ & Financial sector & 13 \\
\hline $\mathbf{4}$ & Health care & 8 \\
\hline $\mathbf{5}$ & Real Estate & 7 \\
\hline $\mathbf{6}$ & Hotels and restaurants & 7 \\
\hline $\mathbf{7}$ & Production & 7 \\
\hline $\mathbf{8}$ & Energy & 3 \\
\hline $\mathbf{9}$ & Agriculture & 2 \\
\hline $\mathbf{1 0}$ & Architecture & 2 \\
\hline $\mathbf{1 1}$ & Education & 2 \\
\hline $\mathbf{1 2}$ & Mining industry & 2 \\
\hline $\mathbf{1 3}$ & Software & 2 \\
\hline $\mathbf{1 4}$ & Other & 4 \\
\hline & Total & $\mathbf{9 7}$ \\
\hline
\end{tabular}

Source: Results of survey

Surveyed companies have been working on Georgian market for at least seven years. Relatively new comers are the representatives from the fields of software, mining industry, health care, hotels and restaurants. 
Table 2. The average index of the years of operation of the surveyed companies in Georgia according to the sectors

\begin{tabular}{|c|c|c|}
\hline & Sector & Average number of operating in Georgia \\
\hline $\mathbf{1}$ & Trade & 7 \\
\hline $\mathbf{2}$ & Construction & 8 \\
\hline $\mathbf{3}$ & Financial sector & 6 \\
\hline $\mathbf{4}$ & Health care & 5 \\
\hline $\mathbf{5}$ & Real Estate & 7,5 \\
\hline $\mathbf{6}$ & Hotels and restaurants & 3,5 \\
\hline $\mathbf{7}$ & Production & 7 \\
\hline $\mathbf{8}$ & Energy & 6,3 \\
\hline $\mathbf{9}$ & Agriculture & 8 \\
\hline 10 & Architecture & 6,5 \\
\hline 11 & Education & 6,5 \\
\hline 12 & Mining industry & 3,5 \\
\hline 13 & Software & 3 \\
\hline 14 & Other & 15 \\
\hline 15 & Average index in total & 7 \\
\hline
\end{tabular}

Source: Results of survey

Table 3. Number of people employed in surveyed companies according to sectors

\begin{tabular}{|c|c|c|c|}
\hline & Sector & $\begin{array}{c}\text { Number of people emplo- } \\
\text { yed in total }\end{array}$ & $\begin{array}{c}\text { Number of people emplo- } \\
\text { yed in Georgia }\end{array}$ \\
\hline $\mathbf{1}$ & Trade & 65 & 61 \\
\hline $\mathbf{2}$ & Construction & 7997 & 4585 \\
\hline $\mathbf{3}$ & Financial sector & 307 & 287 \\
\hline $\mathbf{4}$ & Health care & 92 & 167 \\
\hline $\mathbf{5}$ & Real Estate & 175 & 484 \\
\hline $\mathbf{6}$ & Hotels and restaurants & 535 & 628 \\
\hline $\mathbf{7}$ & Production & 642 & 68 \\
\hline $\mathbf{8}$ & Energy & 68 & 158 \\
\hline $\mathbf{9}$ & Agriculture & 160 & 61 \\
\hline $\mathbf{1 0}$ & Architecture & 65 & 116 \\
\hline $\mathbf{1 1}$ & Education & 116 & 31 \\
\hline $\mathbf{1 2}$ & Mining industry & 41 & 87 \\
\hline $\mathbf{1 3}$ & Software & 96 & 456 \\
\hline $\mathbf{1 4}$ & Other & 456 & $\mathbf{7 2 8 1}$ \\
\hline & Total & 10815 & 92 \\
\hline
\end{tabular}

Source: Results of survey 
As the table shows, foreign direct investments in the construction sector are less likely to employ Georgian citizens and mainly employ foreign workers, which indicate that the sector does not have a positive impact on the employment rate on the one hand, but on the other hand this may be caused by low level of qualification of workers. This opinion is confirmed in different parts of our research, for instance, MNEs consider that one of the most important obstacles in Georgia is unqualified staff.

The majority of interviewed companies are from Turkey, also the US, German, Netherlands, Azerbaijan and Russian companies.

Diagram 1 Companies surveyed according to the countries

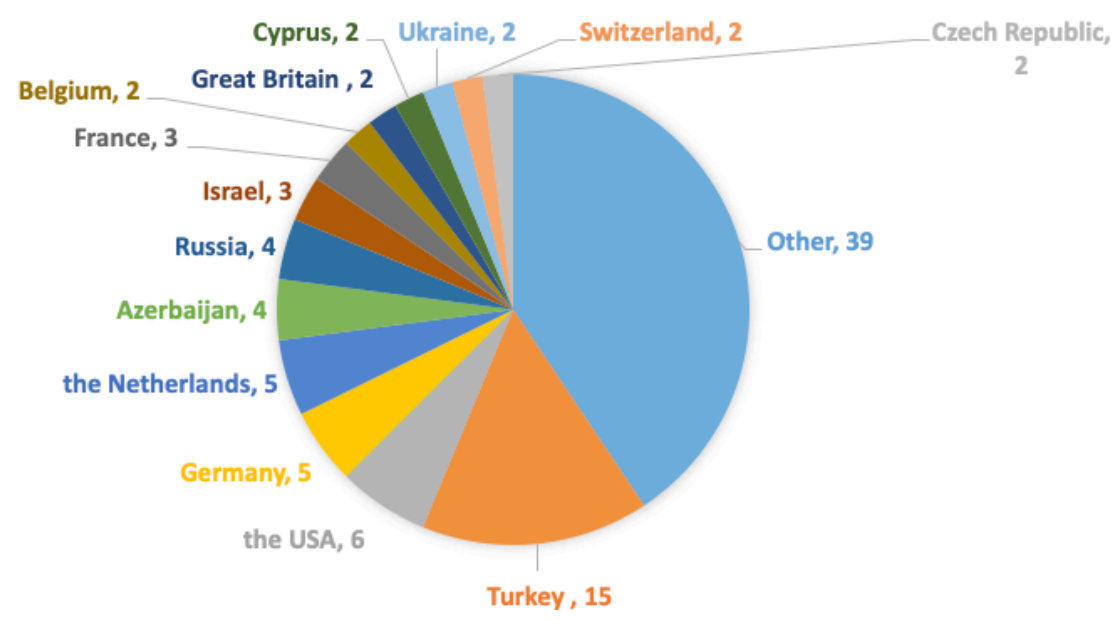

Source: Results of survey

\section{Analysis of average indicators}

One of the most important issues in our research is the creation of linkages with local organizations by foreign companies. To this, we asked investors two different questions, the first of which was about the number of linkages with local firms, and the second with the quality of cooperation with them.

To the question concerning how many local organizations are cooperating with MNEs and how close they cooperate with them, we received the answers and grouped these answers as follows: Suppliers; Distributors; Financial Intermediaries Research Centers; Universities; Marketing Organizations; Social Organizations; NGOs; Other.

Estimated answers are expressed based on the Ordinal Scale with a 5-point system (0 to 4 points), where:
0 point - none
3 points - from 11 to 30
1 point - from 1 to 5
4 points -31 and more

2 points - from 6 to 10

In addition, from 0 to 4 points they should indicate the quality of the existing density with the relevant companies where:

0 - do not cooperate;

3 - often;

1 - rarely;

4 - very often.

2 - with average frequency; 
The analysis of the results of the received answers' average indicator revealed that MNEs mostly cooperate with suppliers and distributors as well. There is a close connection with the representatives of suppliers, distributors and financial sector. It is noteworthy that the results are quite pessimistic, since the MNEs cooperate with only those organizations that are necessary in the operational field, but do not provide for the dissemination and introduction of new knowledge for organizations operating in Georgia.

Table 4. Forming ties with local economy according to quantity and frequency

\begin{tabular}{|c|c|c|c|c|}
\hline & Mean $^{*}$ & Std. Err. & [95\% Conf. & Interval] \\
\hline Quantity & & & & \\
\hline Suppliers & 2.4 & .2201398 & 1.954725 & 2.845275 \\
\hline Distributors & 1.05 & .1959526 & .6536484 & 1.446352 \\
\hline Financial sector & 0.75 & .0930261 & .5618371 & .9381629 \\
\hline Research centres & 0.65 & .1216869 & .4038651 & .8961349 \\
\hline Universities & 0.55 & .1599279 & .2265154 & .8734846 \\
\hline Marketing organizations & 0.55 & .1129443 & .3215486 & .7784514 \\
\hline Social organizations & 0.4 & .1120897 & .1732772 & .6267228 \\
\hline NGOs & 0.2 & .0733799 & .0515751 & .3484249 \\
\hline Other & 1.125 & .1900995 & .7404875 & 1.509513 \\
\hline Frequency & & & & \\
\hline Suppliers & 2.65 & .2073953 & 2.230503 & 3.069497 \\
\hline Distributors & 1.50 & .2581989 & .9777435 & 2.022257 \\
\hline Financial sector & 1.45 & .2319096 & .9809186 & 1.919081 \\
\hline Research centres & 0.85 & .1662173 & .5137937 & 1.186206 \\
\hline Universities & 0.75 & .1985525 & .3483898 & 1.15161 \\
\hline Marketing organizations & 0.85 & .1879375 & .4698605 & 1.23014 \\
\hline Social organizations & 0.6 & .1593255 & .2777338 & .9222662 \\
\hline NGOs & 0.3 & .1198289 & .0576231 & .5423769 \\
\hline Other & 1.075 & .2159876 & .6381239 & 1.511876 \\
\hline
\end{tabular}

${ }^{*}$ Average indicators

Source: Results of survey

In order to estimate the major problems faced by the investors in Georgia, we have identified the list of the main problems with the ordinal scale of 0 to 4 points where minimum - 0 means a minor problem and the maximum 4 means a very important problem. From the received answers, it is clear that the main problematic issue for MNEs is the instability and inflation of the exchange rate ${ }^{1}$, followed by an unstable political environment, unstable economic environment, unskilled personnel and nonexemplary legislation.

It is noteworthy that according to the FDI global trends, the instability of the exchange rate and inflation is also named as the most important problem. In our case, unqualified staff is important because it prevents the efficiency seeking FDI 's entry, which cannot provide new knowledge, accompanied by this type of foreign direct investment.

1 It should be noted that according to UNCTAD's 2016 survey, investors estimate these two problems as important; it is highlighted in the analysis of the world's investment trends. 
Diagram 2. The main problems identified by investors

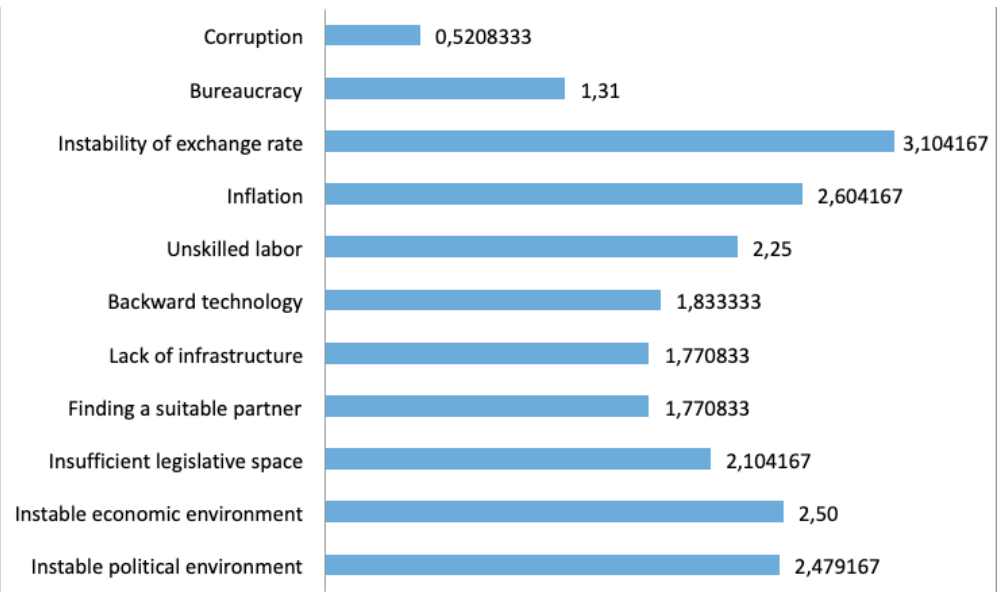

Source: Results of survey

In order to determine the motivation of the foreign direct investments in Georgia, we have identified the main list and used a binary scale where the 0 means that the specific motivation is not the determining factor for the MNEs, and 1 means that it is. Based on the analysis of the average indicator of the received answers, it was revealed that the FDI oriented on the untapped market is a leader; it is followed by low taxes, know-how and more opportunity for quality control.

Table 5. Average Index of Foreign Direct Investments Motivations Based on Investor's Assessments

\begin{tabular}{|c|c|c|c|c|}
\hline Mean estimation & Number of obs & 97 & & \\
\hline & Mean & Std. Err. & $\begin{array}{c}\text { [95\% Conf. } \\
\text { Interval] }\end{array}$ & \\
\hline Natural resources & .0927835 & .0296111 & .0340058 & .1515612 \\
\hline Cheap labour & .1237113 & .0336041 & .0570077 & .190415 \\
\hline Qualified workers & .1340206 & .0347699 & .0650028 & .2030384 \\
\hline $\begin{array}{c}\text { Increased demand from } \\
\text { suppliers and consumers }\end{array}$ & .3298969 & .0479871 & .2346433 & .4251505 \\
\hline Untapped market & .3402062 & .0483548 & .2442227 & .4361897 \\
\hline Imitate the competitors & .0824742 & .0280758 & .0267441 & .1382043 \\
\hline Scale economy & .1030928 & .031035 & .0414887 & .1646968 \\
\hline Strategic assets & .1134021 & .0323622 & .0491636 & .1776405 \\
\hline Know-how & .1649485 & .0378787 & .0897598 & .2401371 \\
\hline Less transportation costs & .0309278 & .0176692 & -.0041453 & .0660009 \\
\hline Cheap production factors & .0412371 & .0202938 & .0009542 & .0815201 \\
\hline Cheap energy resources & .0206186 & .0145034 & -.0081704 & .0494076 \\
\hline $\begin{array}{c}\text { Increased demand from } \\
\text { Georgian consumers }\end{array}$ & .257732 & .0446405 & .1691213 & .3463426 \\
\hline Low taxes & .1958763 & .0405058 & .115473 & .2762796 \\
\hline
\end{tabular}




\begin{tabular}{|c|c|c|c|c|}
\hline Mean estimation & Number of obs & 97 & & \\
\hline & Mean & Std. Err. & $\begin{array}{c}\text { [95\% Conf. } \\
\text { Interval] }\end{array}$ & \\
\hline $\begin{array}{c}\text { Less custom tariffs } \\
\begin{array}{c}\text { More opportunity for quality } \\
\text { control }\end{array}\end{array}$ & .1340206 & .0347699 & .0650028 & .2030384 \\
\hline
\end{tabular}

Source: Results of survey

Based on the results obtained, it is noteworthy that qualified workers in Georgia are not the significant motivation of foreign direct investment for the MNEs. Therefore, we can assume that there is no possibility for Georgian of absorption benefits from the FDI, as many scholars think that the gaining of knowledge from the MNEs related to the field is largely dependent on the skills of local human resources (Lall, 1996; Borensztein, De Gregorio, \& Lee 1998). According to the above mentioned points, developing countries, having less skilled workers, are less likely to benefit from the FDI than those countries that have highly qualified human resources.

\section{Probit model for binary and ordinary variables}

Table 6. The impact of foreign direct investment motivation on exports

\begin{tabular}{|c|c|c|c|}
\hline Ordered probit regression & & & \\
\hline Export & Coef. & Std. Err. & P>z \\
\hline Natural resources & 1.371533 & .6363213 & 0.031 \\
\hline Cheap labour & 1.365003 & .7931201 & 0.085 \\
\hline Qualified workers & .9043415 & .5299922 & 0.088 \\
\hline Untapped market & .1673893 & .3894507 & 0.667 \\
\hline Strategic assets & -.65432 & .6185188 & 0.290 \\
\hline Cheap energy & -1.365003 & 815.1518 & 0.999 \\
\hline Low taxes & -3.997866 & 576.3991 & 0.994 \\
\hline Less customs tariff & 3.920873 & 576.3993 & 0.995 \\
\hline LR chi2(8) & 16.68 & & \\
\hline Pseudo R2 & 0.1681 & & \\
\hline Number of obs & 68 & & \\
\hline
\end{tabular}

Source: Results of survey

This equation consists of one dependent variable (export) and it is determined by the scale 0-4. As we can see, natural resources seeking FDI has a positive impact on export growth, which asserts the opinion that natural resources seeking FDI contributes to the development of trade, but it does not mean that it is integrated with the local economy. This will be seen in a regression equation reflecting the impact of motivation on the formation of local economy. As for the efficiency seeking FDI (cheap labour, qualified employee), it has a positive impact on export activities, which confirms the opinion of literature. MNEs, whose primary motivation is small taxes, are not oriented on export. The strategic assets-seeking FDI influence is unimportant, it was expected, as the advantage of the location does not contribute the strategic assets seeking FDI to use the advantage of its own assets effectively. 
Table 7. Impact of Foreign Direct Investments Motivation on Import

\begin{tabular}{|c|c|c|c|}
\hline Ordered probit regression & & & \\
\hline Import & Coef. & Std. Err. & P>z \\
\hline Natural resources & -.5893072 & .5280135 & 0.264 \\
\hline Cheap labour & .0537496 & .4778145 & 0.910 \\
\hline Qualified workers & -.3842724 & .3839488 & 0.317 \\
\hline Untapped market & -.0253609 & .2804112 & 0.928 \\
\hline Strategic assets & .3883621 & .5198193 & 0.455 \\
\hline Cheap energy & -.0537496 & 430.4847 & 1.000 \\
\hline Low taxes & -5.624596 & 304.3985 & 0.985 \\
\hline Less customs tariff & 5.982198 & 304.3987 & 0.984 \\
\hline LR chi2(8) & 42837.00 & & \\
\hline Pseudo R2 & 0.0593 & & \\
\hline Number of obs & 70 & & \\
\hline
\end{tabular}

Source: Results of survey

The natural resources seeking FDI does not influence imports that can be explained by the fact that local resources are used (not in line with the theory), while the effectiveness seeking FDI's impact on imports is insignificant as well as the marketseeking FDI, which is natural because the market seeking FDI - due to its essence - does not support international trade, but it can be explained by the fact that they buy the necessary resources the local economy. Strategic assets seeking FDI has a positive effect on imports because it focuses on high-tech sectors in its essence, therefore high-tech products are not produced locally and are coming from abroad. In this case, taxes do not significantly affect import activity, and customs tariffs have a positive impact on it.

Table 8. Impact of Foreign Direct Investments Motivations on Innovations

\begin{tabular}{|c|c|c|c|}
\hline Probit regression & & & \\
\hline Innovations & Coef. & Std. Err. & P>z \\
\hline Natural resources & .8410434 & .5926749 & 0.156 \\
\hline Cheap labour & -1.476423 & .6615065 & 0.026 \\
\hline Qualified workers & .1488448 & .521075 & 0.775 \\
\hline Untapped market & .6133413 & .3606247 & 0.089 \\
\hline Strategic assets & -1.266789 & .7129983 & 0.076 \\
\hline Increased demand & .2138837 & .3961029 & 0.589 \\
\hline Low taxes & .9372068 & .8888305 & 0.292 \\
\hline Less customs tariff & -2.086887 & 1.050461 & 0.047 \\
\hline LR chi2(8) & 18.57 & & \\
\hline Pseudo R2 & 0.1533 & & \\
\hline Number of obs & 90 & & \\
\hline
\end{tabular}

Source: Results of survey 
By this equation we assess the influence of FDI motivations on innovative activity. As shown in the table, natural resources seeking FDI have a positive influence on innovations; positive effects are shown also from the market seeking and efficient seeking FDIs, which focus on qualified staff. However, the quality of this influence is insignificant.

\section{Frequency of linkages with local organizations}

Table 9. The impact of foreign direct investments motivations on the number of linkages with suppliers

\begin{tabular}{|c|c|c|c|}
\hline Ordered probit regression & & & \\
\hline Number of ties with the suppliers & Coef. & Std. Err. & P>z \\
\hline Natural resources & .7248722 & .4245344 & 0.088 \\
\hline Cheap labour & .7680726 & .4123739 & 0.063 \\
\hline Qualified workers & .0450123 & .3605062 & 0.901 \\
\hline Untapped market & -.4794413 & .2581782 & 0.063 \\
\hline Strategic assets & -.2199877 & .3864765 & 0.569 \\
\hline Cheap energy & -1.152369 & .9449799 & 0.223 \\
\hline Low taxes & -.9972867 & .5584999 & 0.074 \\
\hline Less customs tariff & .7626909 & .6251746 & 0.222 \\
\hline LR chi2(8) & 14.19 & & \\
\hline Pseudo R2 & 0.0558 & & \\
\hline Number of obs & 84.00 & & \\
\hline
\end{tabular}

Source: Results of survey

With this regression equation, we estimate the impact of foreign direct investments' motivations on the development of local industries by estimating the integration of foreign firms with the local economy. The aim of this regression is to define the impact of each motivation on the formation of links with local suppliers. As the table shows, the natural resources seeking FDI has a positive impact on the formation of local ties, which further reinforces our view in the table - "Assessment of FDl's Impact on Import" - that natural resources seeking use local resources in their industry, which is expressed in their ties with local suppliers. As for the effectiveness seeking FDI, they also have a positive impact on the formation of ties, but the effectiveness seeking FDl's effectiveness (which focuses on the use of qualified personnel) is insignificant for establishing ties with local suppliers. Finding strategic assets, using cheap energy, small taxes, is not a key factor for the formation of links with suppliers.

Table 10. Influence of Foreign Direct Investment Motivations on the number of linkages with distributors

\begin{tabular}{|c|c|c|}
\hline Number of linkages with the distributors & Coef. & Std. Err. \\
\hline Natural resources & .5857651 & .4933559 \\
\hline Cheap labour & .7711078 & .4976571 \\
\hline Qualified workers & -.035912 & .3967361 \\
\hline Untapped market & .1507752 & .2697134 \\
\hline Strategic assets & -.3627903 & .5001028 \\
\hline
\end{tabular}




\begin{tabular}{|c|c|c|}
\hline Number of linkages with the distributors & Coef. & Std. Err. \\
\hline Cheap energy & -.7728181 & .9895725 \\
\hline Low taxes & -.4580866 & .6000776 \\
\hline Less customs tariff & -.5672569 & .6591848 \\
\hline LR chi2(8) & 9.86 & \\
\hline Pseudo R square & 0.0436 & \\
\hline Number of obs & 74.00 & \\
\hline
\end{tabular}

Source: Results of survey

With this regression equation we estimate the impact of foreign direct investments' motivations on the formation of links with distributors. This table shows that the natural resources seeking FDI has a positive effect on the establishment of linkages with local distributors; low-cost labour force-oriented effectiveness seeking FDI also has a significant impact, while the impact of the qualified personnel seeking FDI is negligible on the formation of linkages with distributors. It is also noteworthy, that the market seeking FDI's influence is also insignificant, though its impact is positive. As for the rest of the motivations, they have negative attitudes to the formation of links with distributors.

Table 11. The impact of foreign direct investments, motivations on the number of linkages with financial intermediaries

\begin{tabular}{|c|c|c|c|}
\hline $\begin{array}{c}\text { Ordered probit regression } \\
\begin{array}{c}\text { Number of linkages with financial } \\
\text { intermediaries }\end{array}\end{array}$ & Coef. & Std. Err. & P >z \\
\hline Natural resources & .7961061 & .5878188 & 0.176 \\
\hline Cheap labour & 1.152239 & .6456979 & 0.074 \\
\hline High qualified workers & .4593807 & .5245539 & 0.381 \\
\hline Untapped market & .173559 & .3436294 & 0.614 \\
\hline Strategic assets & -.2355804 & .5940559 & 0.692 \\
\hline Cheap energy & -8.264089 & 410.0874 & 0.984 \\
\hline Low taxes & $1.449252^{\star * *}$ & .7129127 & 0.042 \\
\hline Less customs tariff & $-2.485982^{\star * *}$ & .7917309 & 0.002 \\
\hline LR chi2(8) & 19.52 & & \\
\hline Pseudo R2 & 0.1675 & & \\
\hline Number of obs & 54 & & \\
\hline
\end{tabular}

Source: Results of survey

With this regression equation we estimate the impact of various motivations of foreign direct investments on the formation of links with financial mediators; from the table it seems that, like in the rest of the case, the natural resources and effectiveness seeking FDI have a positive impact on local financial institutions. Also, the market seeking FDI has a positive impact, although its indicator is insignificant. As for the rest of the motivations, their influence is less important on the formation of links with financial institutions. 
Table 12. Impact of Foreign Direct Investment Motivations on the number of links to research centres

\begin{tabular}{|c|c|c|c|}
\hline Ordered probit regression & & & \\
\hline Number of linkages with research centres & Coef. & Std. Err. & P>z \\
\hline Natural resources & .787603 & .6441995 & 0.221 \\
\hline Cheap labour & -.4885487 & .9436205 & 0.605 \\
\hline High qualified workers & .0289065 & .5319789 & 0.957 \\
\hline Untapped market & 1.742425 & .4106436 & 0.000 \\
\hline Strategic assets & -.6208371 & .6990468 & 0.374 \\
\hline Cheap energy & 1.542336 & 1.200585 & 0.199 \\
\hline Low taxes & .4572525 & .88796 & 0.607 \\
\hline Less customs tariff & -.2692545 & .8806885 & 0.760 \\
\hline LR chi2(8) & 23.26 & & \\
\hline Pseudo R2 & 0.2329 & & \\
\hline Number of obs & 50 & & \\
\hline
\end{tabular}

Source: Results of survey

In the formation of ties on the local economy, it is also important to analyse how the foreign direct investments are integrated with local research centres. Cooperation with them contributes to the diffusion of knowledge and the effect of technology transfer. As shown in the table, natural resource seeking FDI has positive ties with local research centres, but as shown by the table, effectiveness seeking FDI does not have a positive effect on the formation of links with local research centres. It is also important to note that the influence of the strategic assets seeking FDI is negligible on the formation of ties with local research centres, which can be explained by the fact that strategic assets seeking investors are less interested in local research centres because there are no relevant infrastructure and quality research centres in the country.

Table 13. The impact of foreign direct investments' motivations on the number of linkages with universities

\begin{tabular}{|c|c|c|c|}
\hline Ordered probit regression & & & \\
\hline Number of linkages with the universities & Coef. & Std. Err. & P>z \\
\hline Natural resources & .1405801 & .7398654 & 0.849 \\
\hline Cheap labour & .0106416 & .9405179 & 0.991 \\
\hline Qualified workers & -.6272531 & .5861909 & 0.285 \\
\hline Untapped market & .775756 & .3778355 & 0.040 \\
\hline Strategic assets & .0503096 & .7569765 & 0.947 \\
\hline Cheap energy & -4.711126 & 481.9968 & 0.992 \\
\hline Low taxes & -.0266939 & .9070667 & 0.977 \\
\hline Less customs tariff & -.2839074 & .9060966 & 0.754 \\
\hline LR chi2(8) & 8.15 & & \\
\hline Pseudo R2 & 0.0882 & & \\
\hline Number of obs & 49.00 & & \\
\hline
\end{tabular}

Source: Results of survey 
According to the number of linkages with universities, natural resources and untapped markets are distinguished compared to other factors; as for the rest of the motivations, the quality of the coefficient is negligible or negative.

\section{Discussion and conclusions}

According to the regression equations about degree of linkages with MNE's and local firms, influence of foreign direct investments in Georgia is insignificant on the development of local organizations and innovations, therefore it cannot ensure their involvement in research and development. MNEs do not receive the relevant product / service from local organizations and are mainly dependent on resources provided by the head company. According to the empirical studies which are discussed in literature review of this article, FDI can give more benefit to the country when foreign and local economies do not differ significantly from each other. The main obstacle to the development of local organizations is the outdated technology that causes that the FDl's influence on local companies becomes insignificant. According to our research results, the business environment of MNEs operating in Georgia is unequally similar to the Georgian business environment. Due to all the above-mentioned, local organizations have little opportunity to receive benefit from the foreign direct investments, and thus benefit from MNEs - knowledge and experience on innovation. This opinion is confirmed by the results of our survey on whether the foreign subsidiary helps to improve the product or service of the Georgian enterprise (s), as well as whether it implements the innovations in Georgia; we received negative results in this regard. Consequently, it is obvious that local organizations cannot benefit from the advantages of MNEs, which cannot provide them with continuous involvement in research and development. This opinion is supported with the regression equation - despite the positive influence of foreign direct investments in Georgia on the introduction of innovations (natural resources seeking and market seeking, efficiency seeking FDI, which focuses on qualified personnel), the quality of this influence is insignificant.

Although the Georgian market is small and the population is less affordable, it is dominated by the market seeking FDI, which are oriented to serve the local market due to their nature and have no positive impact on export. For most of the surveyed companies, untapped market is a major motivation, accordingly, they are oriented to serve the local market while entering the market and their initial plans do not include products' export.

On the one hand, it will provide new business directions, increase competition in Georgia, which is very beneficial. On the other hand, local organizations can be replaced / excluded from market and the balance of payments - worsened. The idea is supported by the issue of the number and frequency of ties of investors with local organizations, as to this question the investors have noted that they receive essential material / raw materials or services from the local partners but do not have strategic ties or if have - they are too weak. All of the above also indicate that MNEs that are directly engaged in foreign investments in Georgia (except for natural resources seeking FDls), are not integrated with the local market.

- Natural resource seeking companies use local resources in their production, which is expressed in their linkages with local suppliers and distributors. Strategic assets search, use of cheap energy, low taxes are not the main factor for the formation of vendors links, owing to the fact that the strategic 
asset-seeking FDI in its essence is focused on high-tech industries, while in Georgia no high-tech products are produced but they are imported from abroad.

- Unstable exchange rate, inflation, unstable political environment, unstable economic environment, unqualified staff and unsubstantiated legislation - these are the problems named by the MNEs operating in Georgia. It is noteworthy that according to UNCTAD's survey of MNEs (2016), the uncertainty of the exchange rate and the geopolitical situation is also one of the main issues that can lead to a reduction in global FDIs flows. In our case, the attention should be paid to unqualified staff, which often determines the potential inflow of the efficiency seeking FDI in the country. The results of our research show that unqualified staff is one of the most important hindering factors in Georgia to attract FDI. Despite the fact that in our country there are numerous individuals with higher education, in most cases they do not have the education of the narrow field, and for MNEs that are focused on innovations, high technologies production - retraining of staff with relevant education and specialty is quite expensive.

It should also be noted that the above-mentioned issues stipulate less attractiveness of the location advantages, because the MNEs do not have the ability to effectively use their ownership advantages. All these points make the country less attractive to investments.

The issues presented in the paper are important for the development of a foreign direct investment strategy and for the creation of links between MNEs and local organizations. The results of the conducted research are valuable information for the scientific circle as well as the representatives of the country's investment strategy determining state structures that are interested in foreign direct investments. The findings and conclusions of the research carried out on the example of Georgia can be generalized and used in the post-Soviet countries.

The Law of Georgia on Investment Promotion applies special investment promotion regime: an investor, who is planning to make an investment with a total of more than 8 million GEL or which - in functional and strategic point of view - has the significant impact on the country's economy and infrastructure development, has the right to request the Government to grant the status of special significant investment for the investments to be carried out by it. The decision is made by the structural units defined by the Georgian government (ministries, administrative bodies ...). We think it is advisable that the decision on granting the status of a special investment should be made not only according to the volume of investment, but it should be also taken into account the motivation of investments, what are the characteristics of companies of the same sector operating in the local market, how much is the company export-oriented, whether it promotes the distribution of new knowledge, whether it will cooperate with local organizations, whether it will employ local staff, how long their goals are, etc. Conclusions in our work on considering such issues will provide significant assistance to the Government of Georgia when making a decision on granting special status for investment and determining the strategy of attracting foreign direct investments.

In order the country to get more benefits from foreign direct investment, it is important to determine which of the FDI's motivation for the country's economy can be a positive influence on and which sectors have priority, after which it is necessary to increase funding for research and development by a state, as well as by local organizations. Many scholars think that the more investments are made in research and development, the more opportunities are available to get knowledge for the recipient country's firms 
from the MNEs. This opinion is confirmed by the empirical studies conducted on the example of different countries.

Attracting resource seeking and efficiency seeking FDI will contribute more to the proprietary advantages of MNEs develop trade and positive impact on export growth. The results of our survey also confirmed this view because the companies seeking natural resources in Georgia are mainly using local resources and are focused on export. Market seeking FDI, is not interested in export activities, and in some areas it can be utterly useless for the country's economy. For example, according to the results of our survey, most of the employees employed by MNEs in the construction sector are foreign citizens. In addition, MNEs are not oriented on local resources or long-term investments; they operate in Georgia only for four-five years; it means that the aim of such companies is only speculative: they temporarily enter the local market, they are oriented on import, they employ less locals and do not establish business ties with local organizations; it does not support the spread of new knowledge related to the field.

However, it is noteworthy that the lack of skilled labour on the Georgian market represents a significant hindering factor for entering foreign direct investments and receiving benefit from it. One of the important challenges of the Georgian Government in term of the vocational education reform strategy is the lack of educational programs' compliance with the current and future requirements of the labour market. However, it is unclear how the future requirements are determined. It would be better if hightech, export-oriented MNEs are attracted through the creation of vocational education programs and training of the staff with necessary profession during creation and development of professional educational programs. We think this process should be complex and involve several circles: Ministry of Economy and other ministries, according to the specificity of the relevant sector, the Ministry of Education and MNEs.

We believe that the results of our research will provide significant assistance to investment strategy developers in order to determine the country's top priority investment directions, fields and attract MNEs that will have a positive impact on the economy of the country. As well as the researchers who study the positive or negative effects of foreign direct investments in the country's economy.

Funding: The research was supported by Shota Rustaveli National Science Foundation of Georgia (SRNSFG) (grant number MG-TG-18-664) and Caucasus International University (ClU).

\section{References}

Agosin, M. (2005). Foreign investment in developing countries: does it crowd in domestic investment? 149-162.

Borensztein, E., De Gregorio, J., \& Lee, J-W (1998). How does foreign investment affect economic growth? Journal of International Economics, 45(1), 115-135.

Dunning, J. H. (2000). The eclectic paradigm as an envelope for economic and business theories of MNE activity. International Business Review 9, 163-190 .

Hu, A., \& Jefferson, G. (2002). FDI impact and spillover: Evidence from China's. The World Economy, 1063-1076. 
Khaturia, V. (2002). Liberalization, FDI, and productivity spillovers: An analysis of Indian manufacturing firms. Oxford Economic Papers, 688-718.

Kottaridia, C., Giakoulas , D., \& Manolopoulosb, D. (2019). Escapism FDI from developed economies: The role of regulatory context and corporate taxation. International Business Review, 36-47.

Kurdadze, S. (2018, June). http://research.ciu.edu.ge. Retrieved from http://research.ciu. edu.ge.

Nistor, P. (2015). FDI Implications on BRICS Economy Growth. Procedia Economics and Finance, 981-985.

Lall, S. (1996). The investment development path: Some conclusions. In J. Dunning \& R. Narula (Eds.), Foreign direct investment and governments: Catalysts for economic restructuring (pp. 423-441). London: Routledge.

Scott-Kennel, J. (2010). The impact of foreign direct investment on New Zealand industry. Retrieved from https://researchcommons.waikato.ac.nz/bitstream/handle/10289/4724/ thesis.pdf?sequence=3.

Sikharulidze, Kurdadze, Tordinava. (2015). The Impacts of FDI on Domestic Investment (In Case of Georgia). SOCIÁLNO-EKONOMICKÁ REVUE, 35-40.

Sikharulidze, D. (2012). Motivations for foreign direct investment and their impact on Georgia's economy. Economic and Business, 61-78.

Silajdzic, S., \& Mehic, E. (2015). Knowledge Spillovers, Absorptive Capacities and the Impact of FDI on Economic Growth: Empirical Evidence from Transition Economies. Procedia - Social and Behavioral Sciences, 614-623. 